\title{
Portable Generator Thermoelectric Termonitoring IoT sebagai Pembangkit Termal di Daerah 3T (Terdepan, Terluar dan Tertinggal)
}

\author{
Rahmat Bayu Setiawan ${ }^{1}$, Panji Adhi Pradana ${ }^{2}$, Muhammad Abdul Fattah ${ }^{3}$, Khairudin ${ }^{4}$ \\ Jurusan Teknik Elektro Universitas Lampung, Bandar Lampung \\ Jl. Prof. Sumantri Brojonegoro No.1 Bandar Lampung 35145 \\ ${ }^{1}$ Lampung Timur rahmatbayusetiawan93@gmail.com \\ ${ }^{2}$ Pringsewu_email_Panji Adhi Pradana \\ ${ }^{3}$ Lampung Tengah_emaī__Muhammad Abdul Fattah \\ ${ }^{4}$ Bandar Lampung_kahirudinēeng.unila.ac.id_Khairudin
}

Intisari - Energi terbarukan adalah sumber energi yang dihasilkan secara alamiah dan akan terus berkelanjutan jika dikelola dengan baik. Indonesia adalah negara yang terkenal dengan potensi alam yang sangat melimpah. Banyak sumber daya alam yang perlu perhatian dari pemerintah untuk dikembangkan. Pengaplikasian alat yang dapat dikembangkan yaitu di antaranya yaitu melalui termoelektrik yang dipantau melalui IoT secara portable sehingga dapat menjangkau daerah 3T (Tertinggal, Terdepan dan Terluar). Prototipe penghasil energi terbarukan dan ramah lingkungan dalam sistem pembangkit mikro, yang dalam hal ini portable generator termoelektrik termonitoring IoT sebagai pembangkit termal dapat dikembangkan untuk mengatasi pemerataan dan ketersediaan energi listrik di daerah 3T (terdepan, terluar dan tertinggal) berbasis kearifan lokal dapat didesain menggunakan 3-D INVENTOR dan hasil simulasi dari sisi material menggunakan ANSYS serta hasil simulasi dari output yang dihasilkan menggunakan MATLAB. Pembuatan prototipe sesuai dengan konsep dan desain yang telah didapatkan sebelumnya dengan menggunakan software Microroft Visio, software INVENTOR dan evaluasi hasil simulasi dengan menggunakan software MATLAB. Hasil dari pembuatan prototipe akan dilakukan pengujian tingkat gradien suhu terbaik untuk menghasilkan energi optimal, sehingga didapatkan data optimal dalam menyimulasikan micro power plant tersebut. Berdasarkan simulasi yang dilakukan didapatkan data dengan daya minimum sebesar 6,215 W selama 2 menit dan daya maksimum sebesar 19,932 W selama 8 menit Kata kunci - Energi, IoT, Portable Generator Thermoelectric

Abstract - Renewable energy is a source of energy that is generated naturally and will be sustainable if managed properly. Indonesia is a country known for its abundant natural potential. There are many natural resources that need attention from the government to be developed. The development of this power generator tool really requires an understanding of the design of the tools used to get optimal results. The application of tools that can be developed is through thermoelectricity which is monitored via IoT in a portable manner so that it can reach 3T areas (Disadvantaged, Frontier and Outermost). Prototypes for producing renewable and environmentally friendly energy in micro-generating systems, in which IoT-monitored portable thermoelectric generators as thermal generators can be developed to address the distribution and data of electrical energy in 3T (frontier, outermost and disadvantaged) areas based on local wisdom can be designed using 3 -D INVENTOR and simulation of materials using ANSYS and simulation of the output generated from MATLAB. Making prototypes in accordance with the concepts and designs that have been obtained previously using Microroft Visio software, INVENTOR software and evaluation of simulation results using MATLAB software. The results of the prototyping will be tested for the best temperature gradient level to produce optimal energy, so that optimal data can be obtained in simulating the micro power plant. Testing data that has been done, and used as evaluation material in the simulation that is carried out. Based on the simulation, data obtained with a minimum power of 6,215 $\mathrm{W}$ for 2 minutes and a maximum power of 19,932 W for 8 minutes.

Keywords — Energy, IoT, Portable generator thermoelectric 


\section{PENDAHULUAN}

Energi listrik merupakan suatu kebutuhan yang sangat penting untuk menunjang kegiatan sehari-hari. Kegiatan industri, perumahan dan pemerintahan menggunakan sumber energi listrik yang berasal dari Perusahaan Listrik Negara (PLN) maupun dari pembangkitan energi listrik industri itu sendiri. Sumber energi listrik di Indonesia menggunakan beberapa sumber pembangkit energi listrik yaitu bahan bakar fosil dan energi terbarukan. Pembangkit energi berbahan bakar fosil menghasilkan energi dari sumber tersedia yang terbatas di bumi, seperti batu bara dan gas bumi.

Pengolahannya memiliki efek berbahaya untuk lingkungan dan sumber energi tersebut apabila digunakan terus menerus sehingga akan habis. Oleh sebab itu, perlu adanya riset untuk mencari alternatif sumber energi terbarukan.

Energi terbarukan adalah sumber energi yang dihasilkan secara alamiah dan akan terus berkelanjutan jika dikelola dengan baik. Penggunaan generator termoelektrik secara portable dan dapat dipantau secara real time oleh IoT dapat menjadi solusi diversifikasi energi listrik bagi masyarakat daerah 3T yang pada umumnya sulit untuk dijangkau oleh pemerintah dan solusi saat terjadi bencana alam yang mungkin menyebabkan distribusi energi listrik terputus baik karena gempa bumi atau banjir. Sehingga, pemerataan energi listrik untuk daerah 3T dapat diwujudkan.

Generator termoelektrik dirancang dengan konstruksi yang menyesuaikan kondisi alam tempat peletakan alat ini yang dipantau secara real time oleh IoT.

\section{TINJAUAN PUSTAKA}

Cara paling mudah untuk memenuhi persyaratan format penulisan adalah dengan menggunakan dokumen ini sebagai template. Kemudian ketikkan teks anda ke dalamnya.

\section{A. Generator Termoelektrik}

Teknologi termoelektrik bekerja dengan mengonversi energi panas menjadi listrik secara langsung (generator termoelektrik), atau sebaliknya, dari listrik menghasilkan dingin (pendingin termoelektrik). Untuk menghasilkan listrik, material termoelektrik cukup diletakkan sedemikian rupa dalam rangkaian yang menghubungkan sumber panas dan dingin. Prototipe yang dirancang akan menghasilkan sejumlah listrik sesuai dengan jenis bahan yang dipakai. Kerja pendingin termoelektrik pun tidak jauh berbeda. Jika material termoelektrik di aliri listrik, panas yang ada di sekitarnya akan terserap. Dengan demikian, untuk mendinginkan udara, tidak diperlukan kompresor pendingin seperti halnya di mesin-mesin pendingin konvensional. Untuk keperluan pembangkitan listrik tersebut umumnya bahan yang digunakan adalah bahan semikonduktor.

\section{B. Sistem Konversi Energi Panas dengan Termoelektrik}

Kalor mengalir dengan sendirinya dari suatu benda yang temperaturnya lebih tinggi ke benda lain dengan temperatur yang lebih rendah. Fluida kalor tidak perlu dideteksi. Abad ke-19 ditemukan bahwa berbagai fenomena yang berhubungan dengan kerja dan energi. Pertama dilihat bahwa suatu satuan yang umum untuk kalor, yang masih digunakan sekarang dinamakan kalori (kal) dan didefenisikan sebagai kalor yang dibutuhkan untuk menaikkan temperatur 1 gram air sebesar $1{ }^{\circ} \mathrm{C}$ (Giancoli, 2001: 489).

\section{Elemen Peltier}

Elemen peltier atau pendingin termoelektrik (thermoelectric cooler) adalah alat yang dapat menimbulkan perbedaan suhu antara kedua sisinya jika dialiri arus listrik searah pada kedua kutub materialnya, dalam hal ini semikonduktor. Elemen peltier adalah 
merupakan bagian terpenting dari generator termoelektrik, kedua sisi yang terbuat dari keramik memiliki fungsi sebagai sisi panas dan sisi dingin yang kemudian menghasilkan arus positif dan negatif.

\section{METODOLOGI PENELITIAN}

Penelitian ini dilakukan dengan beberapa tahapan yaitu diawali dengan penyusunan konsep dengan membuat sketsa rancangan awal desain prototipe portable generator thermoelectric berdasarkan data-data yang telah diperoleh dari dua referensi yaitu data sekunder dimensi dan spesifikasi alat dan bahan serta proses simulasi menggunakan software ANSYS dan MATLAB yang digunakan berdasarkan jurnal, referensi dan literatur ilmiah, lalu melakukan pembuatan desain 3D dari rancangan konsep yang telah dibuat dengan menggunakan software INVENTOR sehingga didapatkan desain 3D Portable Generator Thermoeletric dan Pembuatan prototipe sesuai dengan konsep dan desain yang telah didapatkan sebelumnya dengan menggunakan software Microroft Visio, software INVENTOR dan evaluasi hasil simulasi dengan menggunakan software MATLAB. Hasil dari pembuatan prototipe akan dilakukan pengujian tingkat gradien suhu terbaik untuk menghasilkan energi optimal, sehingga didapatkan data optimal dalam menyimulasikan micro power plant tersebut. Data pengujian yang sudah dilakukan, dicatat dan dijadikan sebagai bahan evaluasi dalam perbaikan simulasi yang dilakukan.

\section{HASIL DAN PEMBAHASAN}

\section{A. Desain 3-D Portable Generator \\ Thermoelectric}

Hasil tampilan 3-D visual dari perancangan alat ini dapat dilihat pada gambar 4.1 yang merupakan desain 3D Portable Generator Thermoelectric yang dibuat dengan menggunakan aplikasi desain yaitu INVENTOR. Data-data spesifikasi portable generator thermoelectric diperoleh dari data sekunder baik melalui jurnal, referensi maupun literatur ilmiah dari penelitian yang berhubungan.

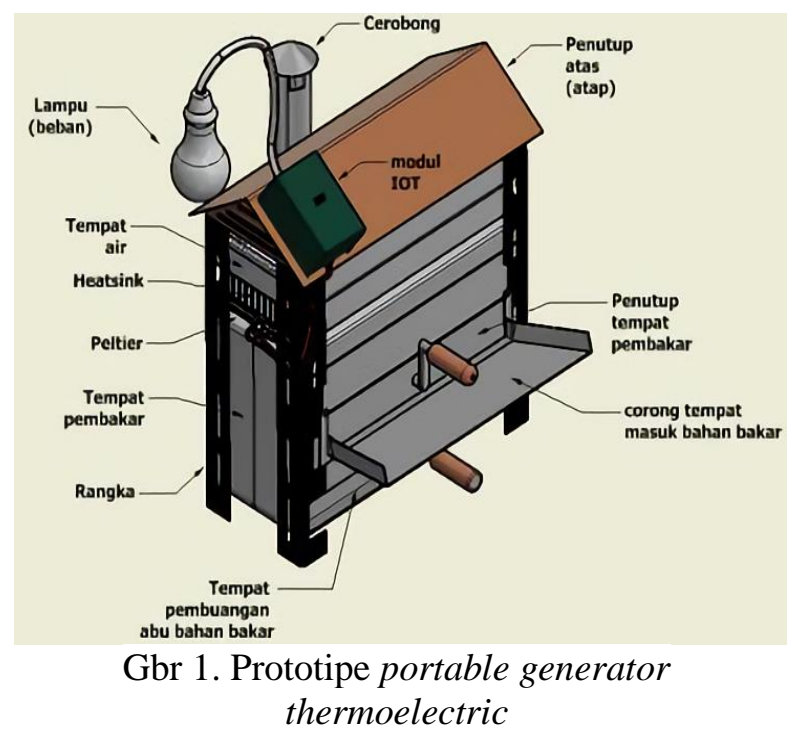

Simulasi portable generator thermoelectric menggunakan MATLAB seperti yang ditunjukkan oleh gambar 2 berikut.

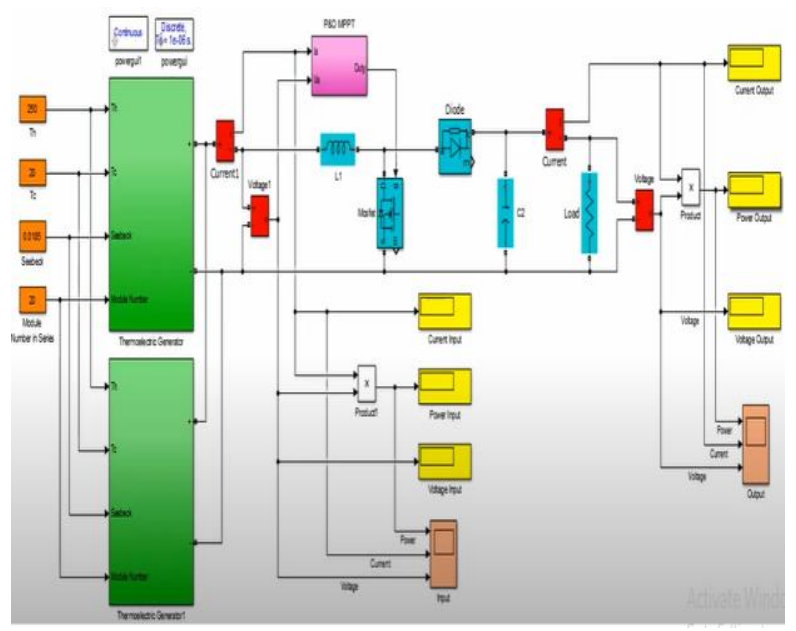

Gbr 2. Simulasi portable generator thermoelectric MATLAB

Hasil simulasi portable generator thermoelectric ditunjukkan oleh gambar 3 berikut.

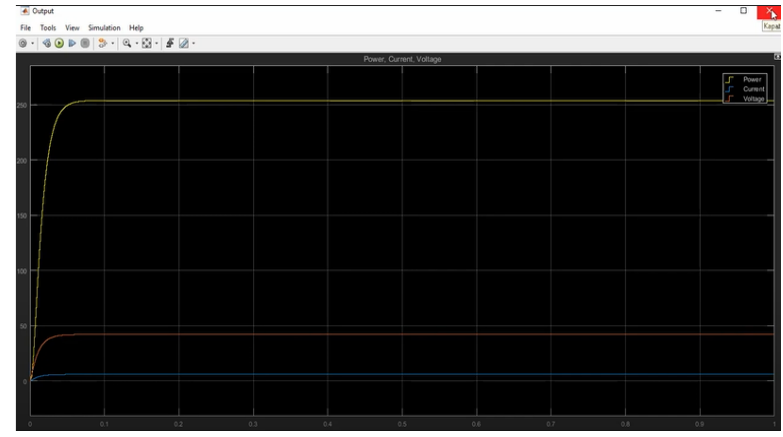

Gbr 3. Hasil simulasi portable generator thermoelectric MATLAB 


\section{PENUTUP}

\section{A. Kesimpulan}

Portable generator thermoelectric dapat menjadi solusi dari ketersediaan energi listrik yang berada di daerah 3T (Terdepan, Terluar Dan Tertinggal) melalui desain 3-D visual dan hasil simulasi menggunakan software Inventor, Matlab dan ANSYS. Pengimplementasian pembangkit listrik termal dengan sumber energi biomassa sudah tersedia di alam dan jumlahnya melimpah di alam. Gradien suhu yang optimal diperoleh melalui simulasi MATLAB dan simulasi terhadap material menggunakan ANSYS sehingga energi yang dihasilkan untuk mencapai hasil terbaik yakni dengan data tegangan, arus, frekuensi, daya aktif dan daya reaktif dengan daya minimum sebesar 6,215 W selama 2 menit dan daya maksimum sebesar 19,932 W selama 8 menit.

\section{UCAPAN TERIMA KASIH}

Terima kasih kepada Kementrian Pendidikan dan Kebudayaan yang telah memberikan dukungan melalui Pendanaan PKM 5 Bidang Tahun 2020.

\section{REFERENSI}

[1] Andriboko, Armansyah, dkk. Peningkatan Kinerja Komputer Dengan Kestabilan Temperatur Terkendali Berbasis Mikrokontroler. Manado: Jurusan Teknik Elektro-FT, UNSRAT, 2015.
[2] Banzi, Massimo. Getting Started with Arduino. USA: Dale Doughety, 2009.

[3] Ekajati, Murdaka, B, dan Priyambodo, Tri Kuntoro. Fisika Dasar Listrik Magnet, Optika, Fisika Modern. Yogyakarta: Andi, 2010.

[4] F. Keith dan A. Priyono. Prinsip-prinsip Perpindahan Panas, edisi ke-3. Jakarta: Erlangga. 1998.

[5] Klara, Sherly dan Sutrisno. Pemanfaatan Panas Gas Buang Mesin Diesel Sebagai Energi Listrik. Volume 14, No. 1. Hal. 113-128. Makassar. 2016.

[6] Koestur, Raldi Artono. Perpindahan Kalor Untuk Mahasiswa Teknik. Jakarta: UI Press. 2002.

[7] Lovell M. C., Avery A. J., Vernon M. W. Physical Properties of Material. Cambridge: Van Nostrand Reinhold Company University Press. 1981.

[8] N. Putra, H. Hardanu, P.A. Sugiarto, F.N. Iskandar. Proceedings of 10th Quality in Research. Depok: IMM-28. 2007.

[9] Nybakken, J. W. Biologi Laut Suatu Pendekatan Ekologis. Jakarta: Gramedia. 1988.

[10] Pramesti, R. Mata Kuliah Biologi Dasar. Fakultas Perikanan dan Ilmu Kelautan, Universitas Diponegoro. 2007.

[11] Putra, Nandy. Dkk. Potensi Pembangkit Daya Termoelektrik Untuk Kendaraan Hibrid. VOL. 13, NO. 2. MAKARA. Depok: Fakultas Teknik, UI. 2009. 